\title{
Functional Anatomy of the Omasum in High Arctic Svalbard Reindeer (Rangifer tarandus platyrhynchus) and Norwegian Reindeer (Rangifer tarandus tarandus)
}

\author{
By S.D. Mathiesen ${ }^{1,2,}$, M.A. Vader ${ }^{1}$, V.B. Raedergård ${ }^{1}$, W. Sørmo ${ }^{2}$, Ø.E. Haga ${ }^{2}$, N.J.C. Tyler ${ }^{3}$ and R.R. \\ Hofmann ${ }^{4}$
}

${ }^{1}$ Department of Arctic Veterinary Medicine, The Norwegian School of Veterinary Science, ${ }^{2}$ Department of Arctic Biology and Institute of Medical Biology, and ${ }^{3}$ Department of Biology, University of Tromsø, Troms $\varnothing$, Norway, and ${ }^{4}$ Institute for Zoo Biology and Wildlife Research, Berlin, Germany.

\begin{abstract}
Mathiesen SD, Vader MA, Radergård VB, Sørmo W, Haga ØE, Tyler NJC, Hofmann RR: Functional anatomy of the omasum in high Arctic Svalbard reindeer (Rangifer tarandus platyrhynchus) and Norwegian reindeer (Rangifer tarandus tarandus). Acta vet. scand. 2000, 41, 25-40. - The structure and fill of the omasum was investigated in summer and in winter in adult female reindeer living on the polar desert and tundra of the high Arctic archipelago of Svalbard and in sub-Arctic mountain habitats in northern Norway. The mean total mass of the omasum in non-lactating adult fe-

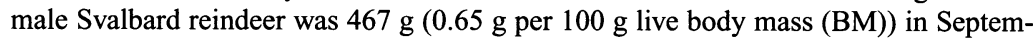
ber and $477 \mathrm{~g}(1.03 \mathrm{~g}$ per $100 \mathrm{~g} \mathrm{BM})$ in April. By contrast, the mean mass of the omasum in non-lactating adult reindeer in northern Norway was $534 \mathrm{~g}(0.83 \mathrm{~g}$ per $100 \mathrm{~g} \mathrm{BM})$ in September but only $205 \mathrm{~g}(0.35 \mathrm{~g}$ per $100 \mathrm{~g} \mathrm{BM} \mathrm{p}<0.05)$ in late March, owing to a decrease in both tissue mass and the wet mass of the contents of the organ. The mean absorptive surface of the omasum in Svalbard reindeer was $2300 \mathrm{~cm}^{2}$ in September and $2023 \mathrm{~cm}^{2}$ in April. In Norwegian reindeer, by contrast, the absorptive surface area decreased from $2201 \mathrm{~cm}^{2}$ in September to $1181 \mathrm{~cm}^{2}(\mathrm{p}<0.05)$ in late March. The marked seasonal decline of omasal tissue and contents in Norwegian reindeer probably results from intake of highly digestible forage plants, including lichens, in winter. Svalbard reindeer, a non-migratory sub-species, survive eating poor quality fibrous vascular plants in winter. The absence of any marked seasonal change in the mass, total absorptive surface area or filling of the omasum in Svalbard reindeer in winter despite a substantial decline in body mass presumably reflects their need to maintain maximum absorption of nutrients, including volatile fatty acids, when feeding on such poorly fermentable forage.
\end{abstract}

Cervid; gastrointestinal tract; Rangifer; ruminant.

\section{Introduction}

Reindeer and caribou (Rangifer tarandus) live throughout the Arctic and sub-Arctic where they are subjected to extreme seasonal variation in the abundance, nutritional quality and availability of forage. The general strategies which the animals have evolved to cope with poor nutritional conditions in winter include a pro- nounced seasonal fluctuation in appetite. Voluntary dry matter intake is high in summer, reaching a peak in July and August, and falls to its annual nadir in January and February in a cycle corresponding to the seasonal changes in the quality and availability of natural forage (e.g. Larsen et al. 1985, Tyler et al. 1999). Re- 
cently, much attention has been given to the seasonal plasticity of the gross anatomy of the gastrointestinal tract (GIT) of these northern ruminants, particularly the reticulo-rumen (RR), the intestines and the large distal fermentation chamber (caecum and proximal colon, DFC). The data have improved the understanding of anatomical and physiological adaptations to alternating periods of abundance and acute shortage of food and placed reindeer within the general classification of ruminant feeding types proposed by Hofmann (1985) (e.g. Aagnes \& Mathiesen 1996, Mathiesen et al. 1999a,b, Sørmo et al. 1999). To date, however, the omasum has received little attention (Hofmann 2000). The omasum is thought to be the site of absorption of a variety of nutrients including volatile fatty acids (VFA), water from forage and from salivary secretion, minerals, water soluble vitamins and salivary bicarbonates. The relative size of this organ varies considerably between different species of ruminants. It is generally small and perhaps less functional in concentrate selectors (CS) like roe deer (Capreolus capreolus) and moose (Alces alces) (Hofmann \& Stewart 1972, Werner 1990, Hofmann \& Nygren 1992, Holand 1992). In grazers (GR) like African buffalo (Syncerus caffer) and grass-eating intermediates (IM) such as red deer (Cervus elaphus) (Hofmann 1973, 1985, 1989) the omasum is large and, therefore, perhaps more important for the processing of forage rich in dietary fibre.

We examined the structure and filling of the omasum in summer and in winter in adult female reindeer living on the polar desert and tundra of Svalbard and in sub-Arctic mountain habitats in northern Norway. The 2 sub-species, Svalbard reindeer (Rangifer tarandus platyrhynchus) and Norwegian reindeer (Rangifer tarandus tarandus), feed on a variety of vascular plants of high nutrient quality in summer but select different diets in winter. Svalbard rein- deer feed on poor quality, fibrous plants including dry grasses, dwarf shrubs and mosses in winter (Staaland et al. 1983, White \& Staaland 1983, Staaland 1984, Sørmo et al. 1999) while reindeer on the mainland of northern Norway, by contrast, include a substantial proportion of highly digestible lichens in their winter diet ( $\mathrm{a}$ cobsen \& Skjenneberg 1975, Mathiesen et al. 1999b, 2000a).

The ruminal production of volatile fatty acids is much reduced in Svalbard reindeer in winter compared with summer but no such seasonal decline is seen in Norwegian reindeer reflecting the difference in diet between the 2 sub-species (White \& Staaland 1983, Sørmo et al. 1997, Mathiesen et al. 2000a). The difference in winter diet also has an important influence on the gross anatomy of the GIT. In Svalbard reindeer, for example, the reticulo-rumen represented $20 \%$ of live body mass (BM) and the organic dry matter (OM) of the contents of the RR contained as much as $25 \%$ plant lignin in winter (Sørmo et al. 1999). In Norwegian reindeer the contents of the RR comprised only $14 \%$ of BM and its $\mathrm{OM}$ contained only $15 \%$ lignin, again reflecting the inclusion of lichen in the diet (Mathiesen et al. 1999b, 2000b). Svalbard reindeer have shorter intestines and a larger DFC than Norwegian reindeer and thus seem more similar to ruminants of the CS type than Norwegian reindeer. Nevertheless, several characteristics of the digestive system of reindeer and caribou are intermediate between ruminants of the CS and GR type (Hofmann 1985, Aagnes \& Mathiesen 1996, Mathiesen et al. 1999b).

Using this knowledge of the effect of the composition of the diet in winter on fill and structure of the GIT, we predicted that the omasum of Svalbard reindeer would have a relatively small absorptive surface area typical of the CS ruminant-types compared to the omasum of Norwegian reindeer, at least in summer when Svalbard reindeer in particular feed on very 
high quality forage. Furthermore, we predicted that the difference in the absorptive surface area of the omasum between the 2 sub-species would be small in winter when food quality and availability is much reduced both in Svalbard and in northern Norway.

\section{Materials and methods}

Study area

Svalbard reindeer were collected from Nordaustlandet $\left(\mathrm{NA}, 80^{\circ} \mathrm{N}\right)$ and Nordenskiöld Land (NL, $78^{\circ} \mathrm{N}$; Fig. 1) in Svalbard. NA is an island dominated by ice caps which cover about $80 \%$ of the total surface area and is classified as an Arctic desert. The mean annual precipitation is approximately $250 \mathrm{~mm}$ and vegetation is species poor and mostly very scarce (cover $<5 \%$ ). Snow lies on the ice-free ground for 9-10 months annually (Glen 1937). Approximately 300 reindeer live here (Hindrum et al. 1995) feeding on mainly Saxifraga oppositifolia, Salix spp. and a few graminoids (Staaland \& Punsvik 1980, Sørmo et al. 1999).

Vegetated ground in NL is an Arctic tundra. Approximately 4000 reindeer live here (Hindrum et al. 1995) feeding on a variety of vascular plants including grasses and sedges (Carex spp., Poa spp, Luzula spp.), dwarf shrubs (Dryas octapetala, Salix spp.) and mosses, the latter especially in winter (Sørmo et al. 1999). Snow covers the ground for 8-9 months annually. Unlike NA, the climate is unstable with temperatures occasionally rising above freezing even in winter, resulting in alternating periods of thawing and freezing which can produce crusts of ice on the snow through which the reindeer have difficulty in digging to reach the plants beneath. Svalbard reindeer are sedentary, not migratory animals (Tyler \& Øritsland 1989) and, consequently, all important dietary lichens (such as Cladina and Cetraria) have long ago been removed by grazing and trampling from those parts of Svalbard including NA and NL

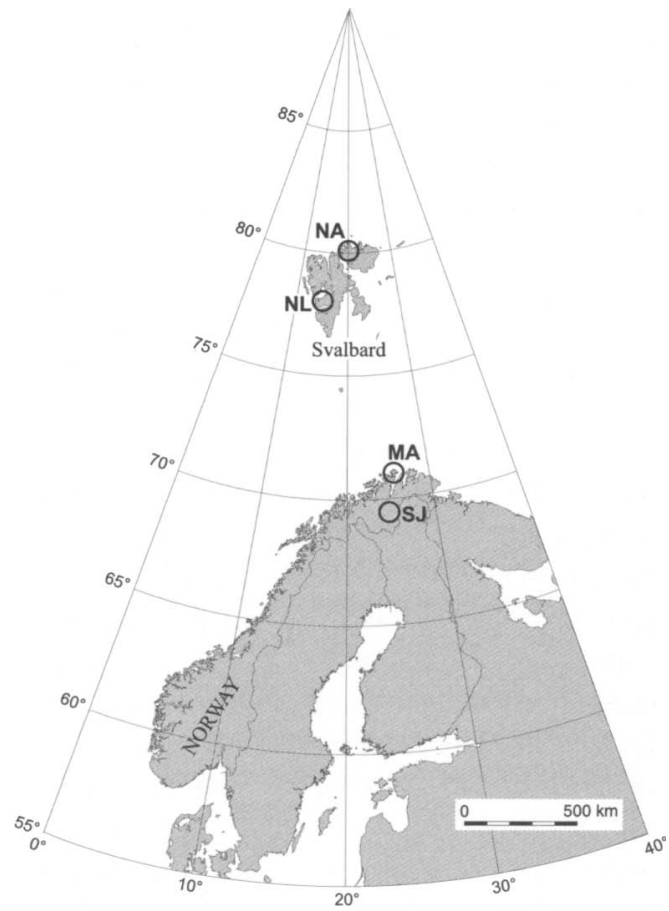

Figure 1. Svalbard reindeer were collected at Nordaustlandet NA (August and April) and Nordenskiöld Land NL (September, October and April) in the high Arctic archipelago of Svalbard and Norwegian reindeer at Magerøya MA (September) and Soussjavre SJ (November-March) in northern Norway.

where there are established populations of reindeer.

Reindeer on the mainland of northern Norway were collected from a herd of semi-domesticated animals in Finnmark $\left(69^{\circ} \mathrm{N}\right)$. This herd migrates about $250 \mathrm{~km}$ between geographically distinct winter pastures inland and a coastal summer pasture (Fig. 1). They eat a wide variety of vascular plants in summer including dwarf shrubs (e.g. Empetrum spp. and Loiseleuria procumbens), birch (Betula nana), willows (Salix spp.), sedges (e.g. Carex spp.) and grasses (e.g. Deschampsia spp., Poa spp.); the 
species composition of their winter diet is similar to their late summer diet except for the inclusion of a significant proportion of lichens (e.g. Cladina spp., Cetraria nivalis, Stereocaulon spp. (Mathiesen et al. 1999b, 2000b).

\section{Animals}

Adult (aged $\geq 2$ years) female Svalbard reindeer, selected at random from groups grazing undisturbed, were killed by a single shot in the chest in April $1994(n=2)$, October $1994(n=$ 7), April $1995(n=4)$, August $1995(n=6)$ and in September $1996(n=12)$. Adult female Norwegian reindeer were selected by hand after the entire herd had been gathered in a paddock, skinned by the traditional saami method of severing the spinal cord with a knife through the foramen magnum and killed by bleeding after cutting the major vessels at the heart in September $1995(n=6)$, November $1995(n=6)$, January $1996(n=6)$ and in March $1996(n=6)$. Post-mortem examination of all animals was carried out in field laboratories starting within 15 min of death. The animals used in this investigation included those described in Sørmo et al. (1999), Mathiesen et al. (1999a,b, 2000b) and Tyler et al. (1999). All animals were classified as lactating or non-lactating based on palpation of the udder.

\section{Body mass}

$\mathrm{BM}$ was recorded to $1 \mathrm{~kg}$ using a Salter mechanical scale (1-100 kg). Hot carcass mass (CM) was measured within $1 \mathrm{~h}$ of death by weighing the dressed carcass to $0.1 \mathrm{~kg}$ on a 150 $\mathrm{kg} \times 50 \mathrm{~g}$ steel yard immediately after the animal was skinned. The dressed carcass is the whole animal less the entire GIT and its contents, the head, the pelt, the lower legs, the uterus and its contents, the udder and all the visceral organs including the kidneys. The head was removed by cutting between the cranium and the first vertebra; the feet were removed by cutting between the distal carpus and the metacarpus and between the distal tarsus and the metatarsus.

\section{Omasum}

The omasum of each animal was separated from the RR and abomasum by cutting at the reticulo-omasal orifice (ROO) and at the omasoabomasal opening, allowed to cool to ambient temperature $\left(0-5^{\circ} \mathrm{C}\right)$ and then weighed to $1 \mathrm{~g}$ on an electronic balance. The length, height and curvature of each omasum were then measured to $1 \mathrm{~cm}$ with a flexible tape according to Hofmann (1973) after which the omasa were carefully opened by cutting along the dorsal curvature. A sample of contents (approximately $10 \mathrm{~g}$ wet mass) was collected from each organ after which omasa were emptied completely, carefully washed out with fresh water, drained and weighed to $1 \mathrm{~g}$ before being fixed in $10 \%$ buffered formalin ( $\mathrm{pH} 7.0)$. The wet mass of the contents of each omasum was calculated by subtraction. A sample of contents was then dried in an oven $\left(115^{\circ} \mathrm{C}\right)$ to constant weight, cooled in a dessicator, weighed to $1 \mathrm{~g}$ and the dry matter content of each omasum was then determined by difference. All first, second and third order omasal leaves (Figs. 2, 3) were dissected out according to Werner (1990) and the surface area of each leaf and of the omasal wall was recorded by tracing their outlines onto transparent plastic and determining the area of the tracings using a computerised digital board. The diameter of the ROO was calculated after opening the organ and measuring the inner circumference of the orifice to $1 \mathrm{~mm}$ with the tissue laid out flat.

\section{Gastroinstestinal tract}

The wet weight of contents and of the tissue of each section of the GIT was measured according to Sørmo et al. (1999) and Mathiesen et al. (1999a,b). 

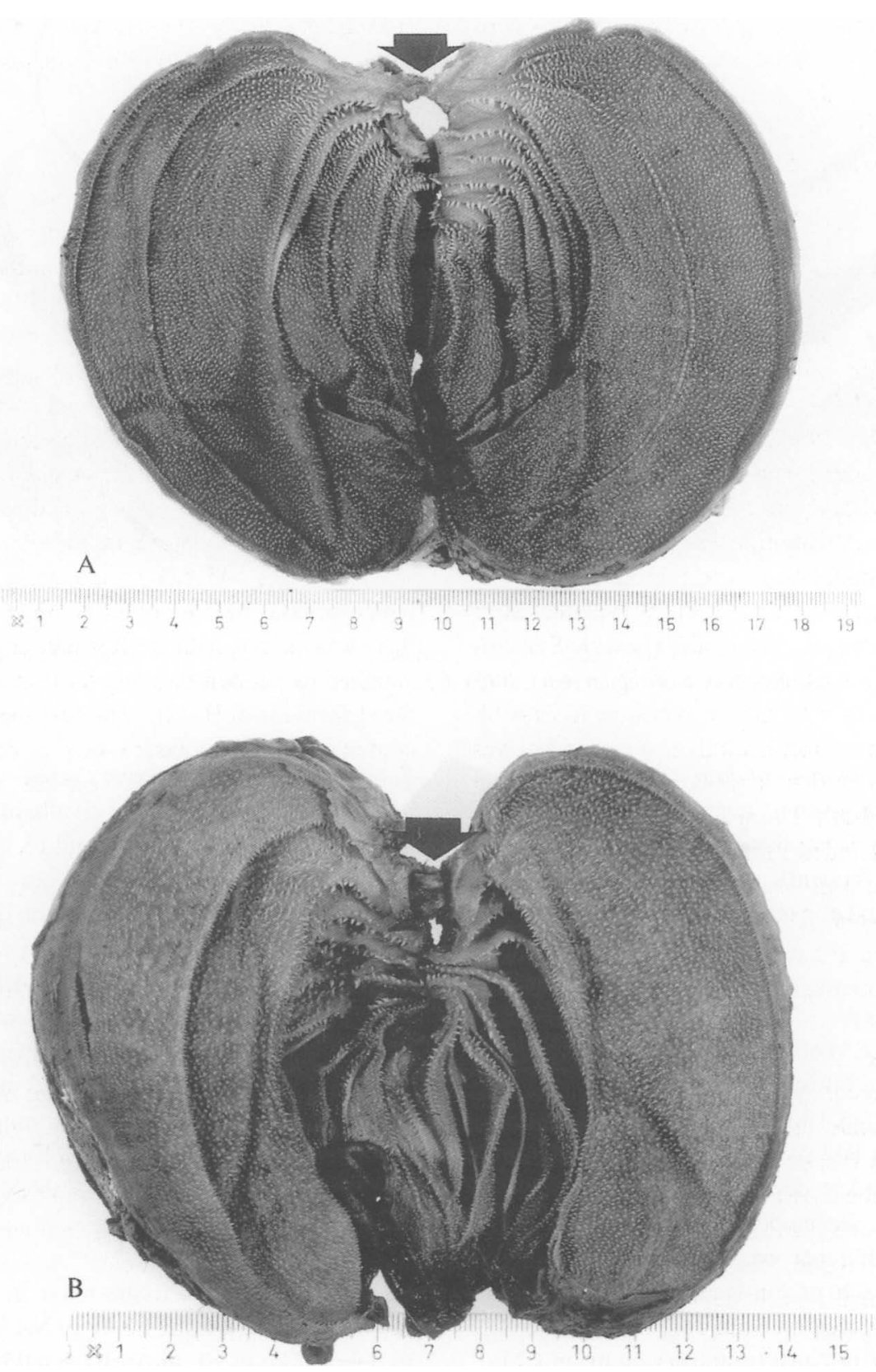

Figure 2. Opened omasa from adult female Svalbard reindeer (A) and adult female Norwegian reindeer (B) in September illustrating the sizes of two different orders of leaves. Arrow: reticulo-omasal orifices. Bar: scale in $\mathrm{cm}$. 

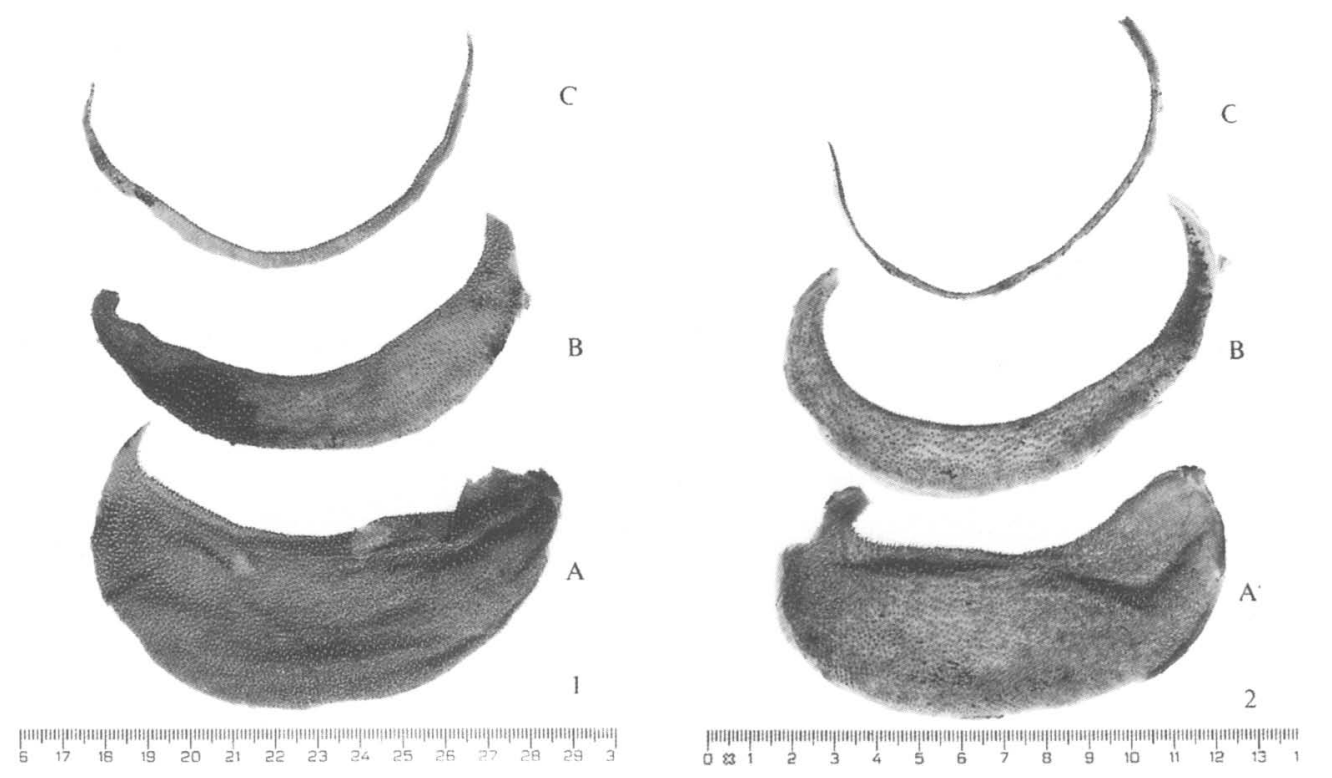

Figure 3. The 1st.-, 2nd.- and 3rd.- order (A, B, C) omasal leaves from the omasa of adult female Svalbard reindeer (1) and adult female Norwegian reindeer (2) in September. Bar: scale in $\mathrm{cm}$.

\section{Statistical analysis of data}

Results are given as mean and standard deviation (SD) from the mean. Significance was tested by Student's $t$-test. The null hypothesis was rejected at $\mathrm{p}<0.05$ in all tests.

\section{Results}

Body mass

The mean BM of non-lactating female Svalbard reindeer in NL declined from $72.1 \mathrm{~kg}$ in September to $46.4 \mathrm{~kg}$ in April ( $<<0.05$, Table 1). The mean BM of Norwegian reindeer showed only a modest decline in winter falling from $65.9 \mathrm{~kg}$ in September to $59.8 \mathrm{~kg}$ in late March, and the difference was not significant (Table 1). The mean CM of non-lactating female Svalbard reindeer decreased from $36.0 \mathrm{~kg}$ in September to $19.9 \mathrm{~kg}$ in April $(\mathrm{p}<0.05)$; the mean $\mathrm{CM}$ of Norwegian reindeer was $30.2 \mathrm{~kg}$ in September and $29.1 \mathrm{~kg}$ in March and the difference was not significant (Table 1).

\section{Total GIT mass (content and tissue)}

The mean mass of GIT in Svalbard reindeer was $16.3 \mathrm{~kg}$ in NA in August and $15.1 \mathrm{~kg}$ in NL in April and the difference was not significant (Table 1). In Norwegian reindeer the mean total GIT was $17.1 \mathrm{~kg}$ in September and $11.9 \mathrm{~kg}$ in March $(p<0.05)$. Likewise mean total mass of the omasum in non-lacating adult female Svalbard reindeer was $466.8 \mathrm{~g}$ in September and $477.0 \mathrm{~g}$ in March. By contrast, the mean mass of the omasum in Norwegian reindeer was $533.7 \mathrm{~g}$ in September and declined to only $205.2 \mathrm{~g}$ in late March $(\mathrm{p}<0.05$, Table 1$)$.

\section{Tissue mass}

The mean total GIT tissue mass in Svalbard reindeer declined from $3.3 \mathrm{~kg}$ in NA in August to only $1.7 \mathrm{~kg}$ in NL in April $(\mathrm{p}<0.05)$ while in Norwegian reindeer mean total GIT tissue declined from $3.6 \mathrm{~kg}$ in September to 2.7 in March but the difference was not significant (Table 1). 
Table 1. Mean (SD) body mass $(\mathrm{kg})$, carcass mass (CM), total mass (g), tissue mass (g), wet mass of contents (wm g) and dry matter (DM g) of the contents of the omasum in adult female Svalbard reindeer (Rangifer tarandus platyrhynchus) and Norwegian reindeer (Rangifer tarandus tarandus).

\begin{tabular}{|c|c|c|c|c|c|c|c|c|c|c|}
\hline \multirow[b]{3}{*}{$\begin{array}{l}\text { Season/ } \\
\text { status }\end{array}$} & \multicolumn{6}{|c|}{ SVALBARD REINDEER } & \multicolumn{4}{|c|}{ NORWEGIAN REINDEER } \\
\hline & \multicolumn{2}{|c|}{ Nord Austlandet } & \multicolumn{4}{|c|}{ Nordenskiöld Land } & \multirow{2}{*}{$\begin{array}{c}\text { Magerøya } \\
\begin{array}{c}\text { September } \\
\text { non- } \\
\text { lactating }\end{array}\end{array}$} & \multicolumn{3}{|c|}{ Suossjarve } \\
\hline & $\begin{array}{c}\text { August } \\
\text { non- } \\
\text { lactating* }\end{array}$ & April* & $\begin{array}{c}\text { September } \\
\text { lactating }\end{array}$ & $\begin{array}{c}\text { September } \\
\text { non- } \\
\text { lactating }\end{array}$ & $\begin{array}{c}\text { October* } \\
\text { non- } \\
\text { lactating }\end{array}$ & April* & & $\begin{array}{l}\text { November } \\
\text { non- } \\
\text { lactating }\end{array}$ & January & March \\
\hline $\mathrm{n}$ & 6 & 2 & 6 & 6 & 7 & 4 & 6 & 6 & 6 & 6 \\
\hline $\mathrm{BM}(\mathrm{kg})$ & $\begin{array}{r}54.2 \\
4.5\end{array}$ & $44.0-59.5$ & $\begin{array}{r}68.9 \\
5.5\end{array}$ & $\begin{array}{r}72.1 \\
5.3\end{array}$ & $\begin{array}{r}64.1 \\
5.3\end{array}$ & $\begin{array}{r}46.4 \\
7.1\end{array}$ & $\begin{array}{r}65.9 \\
8.3\end{array}$ & $\begin{array}{r}63.2 \\
9.7\end{array}$ & $\begin{array}{r}60.1 \\
6.9\end{array}$ & $\begin{array}{l}59.8 \\
10.3\end{array}$ \\
\hline CM (kg) & $\begin{array}{r}23.1 \\
1.7\end{array}$ & $19-27$ & $\begin{array}{r}31.1 \\
3.2\end{array}$ & $\begin{array}{r}36.0 \\
2.7\end{array}$ & $\begin{array}{r}34.6 \\
3.7\end{array}$ & $\begin{array}{r}19.9 \\
2.7\end{array}$ & $\begin{array}{r}30.2 \\
3.3\end{array}$ & $\begin{array}{r}30.0 \\
4.0\end{array}$ & $\begin{array}{r}28.7 \\
3.5\end{array}$ & $\begin{array}{r}29.1 \\
5.0\end{array}$ \\
\hline GIT (kg) & $\begin{array}{r}16.3 \\
1.8\end{array}$ & $10.3-14.8$ & ND & ND & $\begin{array}{r}15.1 \\
1.9\end{array}$ & $\begin{array}{r}13.8 \\
2.4\end{array}$ & $\begin{array}{r}17.1 \\
3.0\end{array}$ & $\begin{array}{r}15.1 \\
3.2\end{array}$ & $\begin{array}{r}13.5 \\
1.5\end{array}$ & $\begin{array}{r}11.9 \\
0.9\end{array}$ \\
\hline $\begin{array}{l}\text { GIT } \\
\text { contents wm } \\
(\mathrm{kg})\end{array}$ & 13.1 & $8.7-13.0$ & ND & ND & $\begin{array}{r}12.8 \\
1.9\end{array}$ & $\begin{array}{r}12.2 \\
2.4\end{array}$ & $\begin{array}{r}13.6 \\
2.1\end{array}$ & $\begin{array}{r}10.9 \\
2.4\end{array}$ & $\begin{array}{l}9.9 \\
1.3\end{array}$ & $\begin{array}{l}9.3 \\
0.9\end{array}$ \\
\hline $\begin{array}{l}\text { GIT } \\
\text { wall }(\mathrm{kg})\end{array}$ & $\begin{array}{l}3.3 \\
0.3\end{array}$ & $1.5-1.8$ & ND & ND & $\begin{array}{l}2.4 \\
0.3\end{array}$ & $\begin{array}{l}1.7 \\
0.1\end{array}$ & $\begin{array}{l}3.6 \\
0.7\end{array}$ & $\begin{array}{l}3.3 \\
1.1\end{array}$ & $\begin{array}{l}3.1 \\
0.3\end{array}$ & $\begin{array}{l}2.7 \\
0.3\end{array}$ \\
\hline $\begin{array}{l}\mathrm{RR} \\
\text { contents wm } \\
(\mathrm{kg})\end{array}$ & $\begin{array}{l}9.9 \\
1.3\end{array}$ & $6.5-10.2$ & $\begin{array}{r}11.2 \\
1.1\end{array}$ & $\begin{array}{l}9.3 \\
1.2\end{array}$ & $\begin{array}{l}9.6 \\
1.7\end{array}$ & $\begin{array}{l}9.3 \\
1.9\end{array}$ & $\begin{array}{r}11.3 \\
2.7\end{array}$ & $\begin{array}{l}8.8 \\
2.0\end{array}$ & $\begin{array}{l}8.1 \\
1.2\end{array}$ & $\begin{array}{l}7.7 \\
0.8\end{array}$ \\
\hline $\begin{array}{l}\mathrm{RR} \text { wall } \\
(\mathrm{kg})\end{array}$ & $\begin{array}{l}2.3 \\
0.3\end{array}$ & $0.9-1.1$ & $\begin{array}{l}2.6 \\
0.1\end{array}$ & $\begin{array}{l}2.2 \\
0.3\end{array}$ & $\begin{array}{l}1.5 \\
0.2\end{array}$ & $\begin{array}{l}1.0 \\
0.1\end{array}$ & $\begin{array}{l}2.9 \\
0.7\end{array}$ & $\begin{array}{l}2.9 \\
0.7\end{array}$ & $\begin{array}{l}2.3 \\
0.3\end{array}$ & $\begin{array}{l}1.9 \\
0.2\end{array}$ \\
\hline $\begin{array}{l}\text { Omasum } \\
\text { total mass } \\
\text { (g) }\end{array}$ & $\begin{array}{l}495.0 \\
135.0\end{array}$ & $375-475$ & $\begin{array}{r}537.3 \\
32.2\end{array}$ & $\begin{array}{l}466.8 \\
184.9\end{array}$ & $\begin{array}{l}543.6 \\
132.1\end{array}$ & $\begin{array}{l}477.0 \\
106.0\end{array}$ & $\begin{array}{l}533.7 \\
102.4\end{array}$ & $\begin{array}{r}300.8 \\
59.1\end{array}$ & $\begin{array}{l}234 \\
44.7\end{array}$ & $\begin{array}{r}205.2 \\
48.6\end{array}$ \\
\hline $\begin{array}{l}\text { Omasum } \\
\text { wall }(\mathrm{g})\end{array}$ & $\begin{array}{r}133.0 \\
28.0\end{array}$ & $99.0-125.0$ & $\begin{array}{r}160.3 \\
48.2\end{array}$ & $\begin{array}{r}167.5 \\
48.6\end{array}$ & $\begin{array}{r}131.7 \\
21.6\end{array}$ & $\begin{array}{r}107.0 \\
12.0\end{array}$ & $\begin{array}{r}225.3 \\
40.1\end{array}$ & ND & $\begin{array}{r}111.9 \\
26.9\end{array}$ & ND \\
\hline $\begin{array}{l}\text { Omasum } \\
\text { contents } \\
\text { wm (g) }\end{array}$ & $\begin{array}{l}363.0 \\
108.0\end{array}$ & $276-350$ & $\begin{array}{r}347.9 \\
47.9\end{array}$ & $\begin{array}{l}314.3 \\
132.9\end{array}$ & $\begin{array}{r}517.5 \\
54.6\end{array}$ & $\begin{array}{r}370.0 \\
98.0\end{array}$ & $\begin{array}{r}383.7 \\
92.8\end{array}$ & ND & $\begin{array}{r}117.8 \\
21.4\end{array}$ & ND \\
\hline $\begin{array}{l}\text { Abomasum } \\
\text { content wm } \\
\text { (g) }\end{array}$ & $\begin{array}{r}251.0 \\
82.0\end{array}$ & $175.0-259.0$ & ND & ND & $\begin{array}{r}203.0 \\
53.0\end{array}$ & $\begin{array}{r}172.0 \\
50.0\end{array}$ & $\begin{array}{l}315.2 \\
121.2\end{array}$ & $\begin{array}{l}287.1 \\
148.0\end{array}$ & $\begin{array}{l}275.9 \\
109.6\end{array}$ & $\begin{array}{r}241.0 \\
83.2\end{array}$ \\
\hline $\begin{array}{l}\text { Omasum } \\
\text { contents } \\
\mathrm{DM}(\mathrm{g} / 100 \mathrm{~g} \\
\text { wet content) }\end{array}$ & $\begin{array}{r}19.5 \\
1.4 \\
\end{array}$ & $25.4-27.8$ & $\begin{array}{r}17.7 \\
2.1\end{array}$ & $\begin{array}{r}16.3 \\
2.8\end{array}$ & $\begin{array}{c}19.0 \\
3.01\end{array}$ & $\begin{array}{c}23.0 \\
0.76\end{array}$ & $\begin{array}{r}17.5 \\
5.5\end{array}$ & $\begin{array}{r}23.1 \\
0.2\end{array}$ & $\begin{array}{r}21.5 \\
1.3\end{array}$ & $\begin{array}{r}23.3 \\
1.3\end{array}$ \\
\hline
\end{tabular}

* Modified data from Sørmo et al. 1999. ND: not determined. 
Table 2. Mean proportion (\%) of omasum total mass, tissue and content wet weight related to the total GIT (gastro-intestinal tract) mass, rumen wet weight content in Svalbard reindeer (Rangifer tarandus platyrhynchus) and Norwegian reindeer (Rangifer tarandus tarandus).

\begin{tabular}{|c|c|c|c|c|c|c|c|c|c|c|}
\hline \multirow[b]{3}{*}{$\begin{array}{l}\text { Season/ } \\
\text { status }\end{array}$} & \multicolumn{6}{|c|}{ SVALBARD REINDEER } & \multicolumn{4}{|c|}{ NORWEGIAN REINDEER } \\
\hline & \multicolumn{2}{|c|}{ Nord Austlandet } & \multicolumn{4}{|c|}{ Nordenskiöld Land } & \multirow{2}{*}{$\begin{array}{c}\text { Magerøya } \\
\begin{array}{c}\text { September } \\
\text { non- } \\
\text { lactating }\end{array}\end{array}$} & \multicolumn{3}{|c|}{ Suossjarve } \\
\hline & $\begin{array}{c}\text { August } \\
\text { non- } \\
\text { lactating* }\end{array}$ & April* & $\begin{array}{l}\text { September } \\
\text { lactating }\end{array}$ & $\begin{array}{c}\text { September } \\
\text { non- } \\
\text { lactating }\end{array}$ & $\begin{array}{c}\text { October* } \\
\text { non- } \\
\text { lactating }\end{array}$ & April* & & $\begin{array}{c}\text { November } \\
\text { non- } \\
\text { lactating }\end{array}$ & January & March \\
\hline $\begin{array}{l}\text { Omasum } \\
\text { total } \\
\text { mass/GIT } \\
\text { total mass } \\
(\%)\end{array}$ & 3.0 & 3.4 & ND & ND & 3.4 & 3.5 & 3.1 & 2.0 & 1.7 & 1.7 \\
\hline $\begin{array}{l}\text { Omasum } \\
\text { contents } \\
\text { wm/RR } \\
\text { contents wm } \\
(\%)\end{array}$ & 3.7 & 3.8 & 3.1 & 3.4 & 5.4 & 4.0 & 3.4 & ND & 1.5 & ND \\
\hline $\begin{array}{l}\text { Omasum } \\
\text { contents } \\
\text { wm/GIT } \\
\text { contents wm } \\
(\%)\end{array}$ & n & 2.9 & ND & ND & 3.3 & 3.0 & 2.8 & ND & 1.2 & ND \\
\hline $\begin{array}{l}\text { Omasum } \\
\text { tissue GIT } \\
\text { wall (\%) }\end{array}$ & 4.0 & 6.7 & ND & ND & 5.5 & 6.3 & 6.3 & ND & 3.6 & ND \\
\hline
\end{tabular}

* Data modified from Sørmo et al. 1999; wm: weight mass.

The mean mass of the tissue of the RR in Svalbard reindeer in NL declined from $2.2 \mathrm{~kg}(3.0 \%$ of $\mathrm{BM})$ in September to $1.0 \mathrm{~kg}$ in April (2.1\% of $B M)(p<0.05)$ and the mean mass of the tissue of the omasum declined from $167.5 \mathrm{~g}$ $(0.23 \%$ of BM) in September to $107.0 \mathrm{~g}(0.23 \%$ of BM) in April, although the difference was not significant. The mean mass of the tissue of the RR in Norwegian reindeer decreased from $2.9 \mathrm{~kg}(4.4 \%$ of BM$)$ in September to $1.9 \mathrm{~kg}$ in March $(3.3 \%$ of $\mathrm{BM})(\mathrm{p}<0.05)$ and the mean mass of the tissue of the omasum declined from $225.3 \mathrm{~g}(0.34 \%$ of BM) in September to 111.9 $\mathrm{g}(0.18 \%$ of BM) in January (Table $1 ; \mathrm{p}<0.05)$.

\section{Mass of contents}

The mean mass of the contents of the GIT content was $13.1 \mathrm{~kg}$ in Svalbard reindeer in NA in August and $12.2 \mathrm{~kg}$ in NL in April ( $\mathrm{p}>0.05)$. In Norwegian reindeer total mass of GIT contents declined from $13.6 \mathrm{~kg}$ in September to $9.3 \mathrm{~kg}$ in March $(\mathrm{p}<0.05$; Table 1). The mean wet weight of the contents of the rumen of Svalbard reindeer was $9.3 \mathrm{~kg}$ both in September and April in NL but in Norwegian reindeer it declined from $11.3 \mathrm{~kg}$ in September to $7.7 \mathrm{~kg}$ in March $(p<0.05)$. The mean wet mass of the contents of the omasum of non-lactating female Svalbard reindeer in NL increased from $314.3 \mathrm{~g}$ in September to $370.0 \mathrm{~g}$ in April but the difference 
Table 3. Mean wet mass of the contents of the GIT (gastrointestinal tract) and RR (reticulo-rumen) as a proportion (\%) of live body mass; mean wet mass of the contents of the omasum as a proportion (\%) of the mean wet mass of the contents of the GIT; and ratio of the mean wet mass of the contents of the DFC (distal fermentation chamber) and the RR in different ruminant feeding types and in Svalbard reindeer (Rangifer tarandus platyrhynchus) and Norwegian reindeer (Rangifer tarandus tarandus). All data are from adult females.

\begin{tabular}{|c|c|c|c|c|c|c|c|}
\hline & \multirow{2}{*}{\multicolumn{2}{|c|}{$\frac{\text { Concentrate selector }}{\text { Roe deer* }}$}} & \multicolumn{4}{|c|}{ Intermediate type } & \multirow{3}{*}{$\begin{array}{l}\text { Grazer } \\
\begin{array}{l}\text { African } \\
\text { buffalo }\end{array} \\
\text { Summer }\end{array}$} \\
\hline & & & \multicolumn{2}{|c|}{ Norwegian reindeer } & \multicolumn{2}{|c|}{ Svalbard reindeer } & \\
\hline & Summer & Winter & Summer & Winter & Summer & Winter & \\
\hline GIT contents wm $\%$ BM & 9.3 & 11.9 & 20.6 & 15.5 & $25.6^{* * *}$ & 26.3 & ND \\
\hline RR contents wm \% BM & 5.8 & 8.9 & 17.1 & 12.9 & 12.8 & 20.0 & 24 \\
\hline RR contents wm \% CM & ND & ND & 37.4 & 26.5 & 25.8 & 46.7 & ND \\
\hline Omasum contents wm \% CM & ND & ND & 1.3 & 0.4 & 0.9 & 1.8 & ND \\
\hline DFC:RR & $1: 7$ & $1: 7$ & $1: 14^{* *}$ & $1: 14^{* *}$ & $1: 10^{* * *}$ & $1: 7^{* * *}$ & $1: 30$ \\
\hline
\end{tabular}

* data from Holand \& Staaland 1985, ** data from Mathiesen et al. 1999b, *** data from Sørmo et al. 1999, $* * * *$ data from Hofmann, 1989, wm: wet mass, bm: bodymass, cm: carcass mass.

was not significant (Table 1). In Norwegian reindeer, by contrast, the mean wet mass of the contents of the omasum decreased from $383.7 \mathrm{~g}$ in September to $117.8 \mathrm{~g}$ in January $(\mathrm{p}<0.05$; Table 1).

\section{Relative mass}

The total mass of the omasum (tissue and contents) in Svalbard reindeer increased from $0.65 \%$ of BM in September to $1.03 \%$ of BM in April. By contrast, the mean total mass of the omasum in Norwegian reindeer decreased by $61.6 \%$ from September $(0.83 \%$ of $\mathrm{BM})$ to March $(0.35 \%$ of BM, $p<0.05$; Table 1$)$. Furthermore, the total mass of the omasum (tissue and contents) in Svalbard reindeer in NA represented $3.0 \%$ of the total mass (tissue and contents) of the GIT in August and 3.4\% in NL in April. In Norwegian reindeer the total mass of the omasum represented $3.1 \%$ of the total mass of the GIT in September but only $1.7 \%$ of GIT mass in March $(\mathrm{p}<0.05$; Table 2).
The omasal tissue in Svalbard reindeer represented $4.0 \%$ of the total mass of the GIT tissue in August in NA and as much as $6.3 \%$ in NL in April. In Norwegian reindeer omasal tissue represented $6.3 \%$ of total GIT in September but only $3.6 \%$ in January ( $<<0.05$; Table 2 ).

The mean wet weight mass of the contents of the GIT comprised $25.6 \%$ of BM in Svalbard reindeer on NA in August and 26.3\% of BM in $\mathrm{NL}$ in April but the difference was not significant. In contrast, in Norwegian reindeer the mean mass of the contents of the GIT declined from $20.6 \%$ of BM in September to $15.5 \%$ of $\mathrm{BM}$ in March ( $\mathrm{p}<0.05$; Table 3$)$. The wet mass of the contents of the RR in non-lactating female Svalbard reindeer in NL increased from $12.8 \%$ of BM and $25.8 \%$ of CM in September to $20.0 \%$ of BM and $46.7 \%$ of CM in April (Table $3 ; \mathrm{p}<0.05$ ). In Norwegian reindeer, by contrast, the wet mass of the contents of the RR decreased from $17.1 \%$ of $\mathrm{BM}$ and $37.4 \%$ of $\mathrm{CM}$ in September to $12.9 \%$ of BM and $26.5 \%$ of 
Table 4. Mean (SD) in selected parameters describing the gross anatomy of the omasum in adult female Svalbard reindeer (Rangifer tarandus platyrhynchus) and adult female Norwegian reindeer (Rangifer tarandus taran$d u s$ ) by location and season.

\begin{tabular}{|c|c|c|c|c|c|c|c|c|}
\hline \multirow[b]{3}{*}{ Season/status } & \multicolumn{5}{|c|}{ SVALBARD REINDEER } & \multicolumn{3}{|c|}{ NORWEGIAN REINDEER } \\
\hline & \multicolumn{2}{|c|}{ Nord Austlandet } & \multicolumn{3}{|c|}{ Nordenskiöld Land } & \multirow{2}{*}{$\begin{array}{c}\text { Magerøya } \\
\text { September } \\
\text { non- } \\
\text { lactating }\end{array}$} & \multicolumn{2}{|c|}{ Soussjavre } \\
\hline & $\overline{\text { August }}$ & $\begin{array}{c}\text { September } \\
\text { lactating }\end{array}$ & $\begin{array}{c}\text { September } \\
\text { non- } \\
\text { lactating }\end{array}$ & $\begin{array}{c}\text { October } \\
\text { non- } \\
\text { lactating }\end{array}$ & April & & $\begin{array}{c}\text { November } \\
\text { non- } \\
\text { lactating }\end{array}$ & March \\
\hline $\mathrm{n}$ & 6 & 6 & 6 & 7 & 4 & 6 & 6 & 6 \\
\hline Length:height ratio & $\begin{array}{l}1.7 \\
0.1\end{array}$ & $\begin{array}{l}1.9 \\
0.1\end{array}$ & $\begin{array}{l}1.9 \\
0.1\end{array}$ & $\begin{array}{l}1.8 \\
0.2\end{array}$ & $\begin{array}{l}1.9 \\
0.1\end{array}$ & $\begin{array}{l}1.8 \\
0.2\end{array}$ & $\begin{array}{l}1.7 \\
0.1\end{array}$ & $\begin{array}{l}1.9 \\
0.1\end{array}$ \\
\hline $\begin{array}{l}\text { Curvature } \\
(\mathrm{cm})\end{array}$ & $\begin{array}{r}24.9 \\
1.5\end{array}$ & $\begin{array}{r}26.0 \\
1.1\end{array}$ & $\begin{array}{r}24.5 \\
3.2\end{array}$ & $\begin{array}{r}26.7 \\
2.0\end{array}$ & $\begin{array}{r}24.8 \\
2.9\end{array}$ & $\begin{array}{r}26.5 \\
2.3\end{array}$ & $\begin{array}{r}20.1 \\
1.2\end{array}$ & $\begin{array}{r}17.8 \\
1.9\end{array}$ \\
\hline $\begin{array}{l}\text { Total absorptive area } \\
\left(\mathrm{cm}^{2}\right)\end{array}$ & $\begin{array}{r}2514.4 \\
516.7\end{array}$ & $\begin{array}{r}2007.7 \\
505.9\end{array}$ & $\begin{array}{r}2300.5 \\
179.0\end{array}$ & $\begin{array}{r}1867.3 \\
312.8\end{array}$ & $\begin{array}{r}2022.8 \\
146.0\end{array}$ & $\begin{array}{r}2200.6 \\
237.4\end{array}$ & $\begin{array}{r}1430.4 \\
219.5\end{array}$ & $\begin{array}{r}1181.0 \\
170.5\end{array}$ \\
\hline $\begin{array}{l}\text { 1st. order leaves } \\
\% \text { total area }\end{array}$ & $\begin{array}{r}50.0 \\
3.6\end{array}$ & $\begin{array}{r}57.7 \\
3.7\end{array}$ & $\begin{array}{r}58.2 \\
2.9\end{array}$ & $\begin{array}{r}54.0 \\
4.2\end{array}$ & $\begin{array}{r}56.9 \\
2.8\end{array}$ & $\begin{array}{r}50.7 \\
2.2\end{array}$ & $\begin{array}{r}47.9 \\
5.0\end{array}$ & $\begin{array}{r}49.4 \\
4.0\end{array}$ \\
\hline $\begin{array}{l}\text { 2nd. order leaves } \\
\% \text { total area }\end{array}$ & $\begin{array}{r}27.9 \\
3.0\end{array}$ & $\begin{array}{r}24.9 \\
2.9\end{array}$ & $\begin{array}{r}21.7 \\
5.3\end{array}$ & $\begin{array}{r}25.8 \\
3.2\end{array}$ & $\begin{array}{r}23.4 \\
1.3\end{array}$ & $\begin{array}{r}29.2 \\
0.9\end{array}$ & $\begin{array}{r}29.6 \\
3.7\end{array}$ & $\begin{array}{r}29.6 \\
2.6\end{array}$ \\
\hline $\begin{array}{l}\text { 3rd order leaves } \\
\% \text { total area }\end{array}$ & $\begin{array}{r}10.5 \\
1.9\end{array}$ & $\begin{array}{l}7.7 \\
1.6\end{array}$ & $\begin{array}{l}6.6 \\
1.3\end{array}$ & $\begin{array}{l}6.8 \\
2.7\end{array}$ & $\begin{array}{l}8.2 \\
1.1\end{array}$ & $\begin{array}{l}7.2 \\
1.5\end{array}$ & $\begin{array}{l}8.1 \\
1.1\end{array}$ & $\begin{array}{l}9.8 \\
1.3\end{array}$ \\
\hline $\begin{array}{l}\text { Wall area } \\
\% \text { total area }\end{array}$ & $\begin{array}{r}11.2 \\
1.9\end{array}$ & $\begin{array}{r}11.4 \\
0.5\end{array}$ & $\begin{array}{r}11.9 \\
1.4\end{array}$ & $\begin{array}{r}13.3 \\
1.3\end{array}$ & $\begin{array}{r}12.4 \\
0.9\end{array}$ & $\begin{array}{r}13.1 \\
0.6\end{array}$ & $\begin{array}{r}14.2 \\
0.9\end{array}$ & $\begin{array}{r}10.3 \\
1.2\end{array}$ \\
\hline 1 st. order leaves (n) & $\begin{array}{r}14.8 \\
1.1\end{array}$ & $\begin{array}{r}18.1 \\
2.2\end{array}$ & $\begin{array}{r}17.7 \\
2.0\end{array}$ & $\begin{array}{r}14.0 \\
1.4\end{array}$ & $\begin{array}{r}13.7 \\
0.4\end{array}$ & $\begin{array}{r}14.5 \\
1.5\end{array}$ & $\begin{array}{r}14.2 \\
0.7\end{array}$ & $\begin{array}{r}14.8 \\
0.7\end{array}$ \\
\hline 2nd. order leaves (n) & $\begin{array}{r}14.6 \\
1.1\end{array}$ & $\begin{array}{r}17.6 \\
2.8\end{array}$ & $\begin{array}{r}16.0 \\
3.3\end{array}$ & $\begin{array}{r}14.0 \\
1.1\end{array}$ & $\begin{array}{r}14.7 \\
0.7\end{array}$ & $\begin{array}{r}15.5 \\
0.9\end{array}$ & $\begin{array}{r}14.0 \\
0.8\end{array}$ & $\begin{array}{r}14.0 \\
0.8\end{array}$ \\
\hline 3rd. order leaves (n) & $\begin{array}{r}26.0 \\
1.5\end{array}$ & $\begin{array}{r}25.7 \\
1.2\end{array}$ & $\begin{array}{r}24.2 \\
2.7\end{array}$ & $\begin{array}{r}23.7 \\
2.8\end{array}$ & $\begin{array}{r}23.7 \\
1.5\end{array}$ & $\begin{array}{r}25.3 \\
1.9\end{array}$ & $\begin{array}{r}24.7 \\
2.1\end{array}$ & $\begin{array}{r}24.5 \\
1.3\end{array}$ \\
\hline Max. leaf height $(\mathrm{cm})$ & $\begin{array}{l}5.0 \\
0.6\end{array}$ & $\begin{array}{l}5.3 \\
0.4\end{array}$ & $\begin{array}{l}4.9 \\
0.6\end{array}$ & $\begin{array}{l}4.9 \\
0.3\end{array}$ & $\begin{array}{l}4.5 \\
0.6\end{array}$ & $\begin{array}{l}5.0 \\
0.3\end{array}$ & $\begin{array}{l}4.0 \\
0.6\end{array}$ & $\begin{array}{l}3.9 \\
0.4\end{array}$ \\
\hline
\end{tabular}

$\mathrm{CM}$ in March (Table 3; $\mathrm{p}<0.05)$.

The wet mass of the contents of the omasum in Svalbard reindeer increased from $0.5 \%$ of $\mathrm{BM}$ and $0.9 \%$ of $\mathrm{CM}$ in September to $0.8 \%$ of $\mathrm{BM}$ and $1.8 \%$ of CM in April (Tables 3\&5; $<<0.05$ ).
In Norwegian reindeer the wet mass of the contents of the omasum represented $0.6 \%$ of $\mathrm{BM}$ and $1.3 \%$ of CM in September and $0.2 \%$ of BM and $0.4 \%$ of $\mathrm{CM}$ in March (Tables 3\&5; $\mathrm{p}<0.05)$. 
Table 5. Relative mean mass and surface area index of omasa in three feeding types of ruminants and in Svalbard reindeer (Rangifer tarandus platyrhynchus) and Norwegian reindeer (Rangifer tarandus tarandus). All data are from adult females.

\begin{tabular}{|c|c|c|c|c|c|c|c|c|}
\hline & \multicolumn{2}{|c|}{$\begin{array}{c}\text { Concentrate selector* } \\
\text { Roe deer } \\
\end{array}$} & \multicolumn{4}{|c|}{$\begin{array}{c}\text { Intermediate type } \\
\text { Reindeer }\end{array}$} & \multicolumn{2}{|c|}{$\begin{array}{c}\text { Grazer } \\
\text { Cattle*** Bison** }\end{array}$} \\
\hline & \multirow[b]{2}{*}{ Summer } & \multirow[b]{2}{*}{ Winter } & \multicolumn{2}{|c|}{ Norway } & \multicolumn{2}{|c|}{ Svalbard } & & \\
\hline & & & Summer & Winter & Summer & Winter & & \\
\hline $\mathrm{BM}(\mathrm{kg})$ & 26 & 25 & 66 & 60 & 69 & 46 & 250 & 400 \\
\hline Surface area index & $25 * *$ & - & 95 & 55 & 92 & 113 & $549 * *$ & $212 * *$ \\
\hline Omasum total wet mass $\% \mathrm{BM}$ & 0.1 & 0.2 & 0.6 & 0.2 & 0.5 & 0.8 & 1.1 & 2.8 \\
\hline Omasum contents dry mass $\% \mathrm{BM}$ & 0.02 & 0.04 & 0.1 & 0.04 & 0.06 & 0.08 & 0.2 & 0.5 \\
\hline $\begin{array}{l}\text { Omasum:abomasum } \\
\text { total weight mass ratio }\end{array}$ & 0.15 & - & 1.2 & 0.4 & 1.4 & 1.5 & - & 13.8 \\
\hline $\begin{array}{l}\text { Omasum contents wet mass } \\
\text { RR contents wet mass }(\%)\end{array}$ & 1.7 & 2.2 & 3.4 & 1.5 & 3.4 & 4.0 & - & 12.9 \\
\hline
\end{tabular}

* data from Holand \& Staaland (1985); ** Surface area index is calculated from Werner (1990) and *** Reed (1983), BM: bodymass.

The wet mass of the contents of the omasum in non-lactating female Svalbard reindeer in NL represented $3.4 \%$ of the mass of the contents of the RR in September and $4.0 \%$ in April. In Norwegian reindeer the wet mass of the contents of the omasum represented $3.4 \%$ of the wet mass of the contents of the RR in September but only $1.5 \%$ in January $(\mathrm{p}<0.05)$ (Tables $1 \& 3$ ).

The ratio of total wet mass of the contents of the omasum and the abomasum was 1.4 in non-lactating female Svalbard reindeer in August but 1.5 in April. In Norwegian reindeer the omasum:abomasum ratio was 1.5 in September but only 0.4 in January (Table $5 ; \mathrm{p}<0.05$ ).

\section{Omasum surface area and other linear measurements}

The largest mean absorptive surface area of any of the omasa measured was $2514.4 \mathrm{~cm} 2$ in Svalbard reindeer from NA in August (Table 4); however, there were no significant differences within seasons in the mass or any of the linear measurements of the omasa in animals from the 2 locations investigated on Svalbard (Tables 1 \& 4).

The mean absorptive surface area of the omasum in non-lactating female Svalbard reindeer showed only a small, non-significant decrease in winter, falling from $2300 \mathrm{~cm}^{2}$ in September to $2023 \mathrm{~cm}^{2}$ in April (Tables 4 \& 5). In contrast, the mean absorptive surface area of the omasum of Norwegian reindeer decreased almost $50 \%$ over the same period from $2201 \mathrm{~cm}^{2}$ in September to $1181 \mathrm{~cm}^{2}$ in March $(\mathrm{p}<0.05$, Tables 4 \& 5).

There were no significant differences in the absorptive surface area, length:height ratio, curvature or the number of first, second and third order leaves and low crests along the omasal curvature of omasa in Svalbard and Norwegian reindeer in September (Table 4). By contrast, the mean length along the curvature of the oma- 
sum in late winter was substantially greater in Svalbard reindeer $(24.8 \mathrm{~cm}, 2.9 \mathrm{SD})$ than in Norwegian reindeer $(17.8 \mathrm{~cm}, 1.9 \mathrm{SD} ; \mathrm{p}<0.05$; Table 4).

\section{Reticulo-omasal orifice}

The mean ROO diameter was significantly larger $(p<0.05)$ in Svalbard reindeer compared to Norwegian reindeer in all seasons. The mean diameter of ROO was 74 mm (SD 10.5) in Svalbard reindeer in NL in September and $65.8 \mathrm{~mm}$ (SD 17.0) in April. The mean ROO diameter in Norwegian mainland animals varied from 40.0 $\mathrm{mm}$ (SD 3.5) in September to $47.7 \mathrm{~mm}$ (SD 3.2) in March.

\section{Effect of reproductive status}

There were no significant differences in any of the omasal parameters between lactating and non-lactating female Svalbard reindeer in September (Table 1,4).

\section{Discussion}

This study demonstrated a pronounced difference in the seasonal dynamics of the gross anatomy and the filling of the omasum in 2 sub-species of reindeer. These differences seem to reflect a major difference in the winter diet of the 2 sub-species, i.e. the inclusion of energyrich lichen in the diet of Norwegian reindeer and the virtual absence of lichens, and an almost total reliance on fibrous vascular plants and mosses, in Svalbard reindeer (Sørmo et al. 1999, Mathiesen et al. 1999b, 2000b). In winter the omasum of Norwegian reindeer declined in the mass of its contents and tissue, and in its absorptive surface area. The omasum of Svalbard reindeer, by contrast, showed no major seasonal reduction either in filling, expressed as the wet mass of the contents of the organ, or in its absorptive surface area.

These differences reflect differences in the nutrition of these 2 sub-species of reindeer in win- ter. Norwegian reindeer show high rates of ruminal production of volatile fatty acids and have relatively small rumens in winter, probably as a consequence of their eating a large proportion of lichens (Mathiesen S.D. et al. 2000a). Lichens, which are composed of fungi and algae, are chemically quite different from vascular plants. Cladina stellaris, a lichen commonly eaten by reindeer in winter, contains as much as $75 \%$ hemi-cellulose and lichen carbohydrates such as lichenin, no cellulose and very little protein ( $<3 \%$ of DM, Person et al. 1980). In contrast to most vascular plants, lichens of the genera Cladina and Cetraria remain highly digestible in reindeer in winter (Jacobsen \& Skjenneberg 1975). Lichens are therefore a good source of metabolisable energy for reindeer and in Norwegian reindeer the ruminal absorptive surface area remained high in winter (Mathiesen et al. 2000b) probably owing to the stimulation of rumen microbial fermentation by the carbohydrates in the lichens. Perhaps not surprisingly, therefore, the mainland animals examined in the present study suffered no net decline in CM in winter (Table 1). The situation was quite different in Svalbard reindeer. In these, ruminal production of VFAs is low and their GIT fill and rumen fill are relatively large (Tables $1 \& 4$ ) reflecting a high intake of poorly digestible fibrous grasses and mosses (Mathiesen et al. 1984, Sørmo et al. 1997). Many of these animals mobilise a large proportion of their energy and protein reserves in winter $(\mathrm{Re}$ imers et al. 1982, Tyler 1987), resulting in a substantial decline in CM (Table 1).

The absorptive surface of the omasum remains large throughout winter in Svalbard reindeer, and the ratio of the mass of the omasal tissue to the total GIT tissue mass increased from summer to winter from $4.0 \%$ to $6.9 \%$, reflecting the need to maintain absorptive function when the animals eat fibrous food. In contrast, in Norwegian reindeer the mass of omasal tissue de- 
creased from $6.3 \%$ to $3.6 \%$ of total GIT tissue mass, respectively. The relatively large omasum in Svalbard reindeer presumably enhances the uptake of nutrients including the small quantity of VFAs produced in their rumens in winter (Sørmo et al. 1997). GR ruminants have large omasa. The organ is believed to have an important role in the processing of fibrous food, CS by contrast, have small omasa and rumens (Table 3; Hofmann 1985). In the muskoxen (Ovibos moschatus), an Arctic ruminant which lives in similar habitats as reindeer and is classified as GR (Hofmann 2000), the mass of omasal tissue was also relatively large in winter $(12.2 \%$ of total GIT tissue; Staaland \& Thing 1991) but was not as large as in domestic cattle (GR;16\% of total GIT tissue; Tulloh 1966). In this respect reindeer are intermediate between ruminants of the GR and CS types, although in winter Svalbard reindeer tend to be more GR like than Norwegian reindeer. GR ruminants have large rumens (Table 3), long ruminal retention of plant particles, low rates of ruminal production of VFA and low ruminal VFA absorption as a result of reduced ruminal papillation. In such animals, the utilisation of plant fibre is enhanced by large omasal absorptive surface area which appears to be important for absorption of VFAs (Hofmann 1973, 1985, 1989).

We found no evidence of omasal hypertrophy in lactating females on Svalbard. The daily maintenance energy requirement of lactating reindeer in Alaska in summer was $457 \mathrm{~kJ} / \mathrm{BM}^{0.75}$ which was almost twice the value of 232 $\mathrm{kJ} / \mathrm{BM}^{0.75}$ in non-lactating females (ChanMcLeod et al. 1994). Lactating animals must therefore consume more digestible energy than non-lactating animals either by eating more or by selecting a more digestible diet. Sørmo et al. (1999) found that lactating females had a larger $\mathrm{RR}$ in autumn compared to non-lactating females. The absence of any omasal hypertrophy in lactating Svalbard reindeer in autumn indi- cates that the omasum cannot be a specifically important site for the absorption of energy rich metabolites in these animals in summer.

Our value for the wet weight of the fill of the omasum of Svalbard reindeer in summer and winter $(5.0$ and $8.0 \mathrm{~g} / \mathrm{kg} \mathrm{BM})$, though slightly larger than the value reported by Staaland et al. (1979) and Staaland \& White (1991), is similar to the value from Norwegian reindeer in sum$\operatorname{mer}(5.8 \mathrm{~g} / \mathrm{kg} \mathrm{BM})$. However, the omasal fill in Norwegian reindeer in winter was much less than in Svalbard reindeer in winter (Table 5). Both subspecies are intermediate in this respect between CS type ruminants (omasal fill $=0.9$ $1.8 \mathrm{~g} / \mathrm{kg} \mathrm{BM}$ ) and GR type ruminants (omasal fill = 11-28 g/kg BM; Table 5), although the value in Norwegian reindeer in winter is close to the value for roe deer (Table 5; Holand \& Staaland 1985). The omasal fill of reindeer was small compared to muskoxen in which omasal wet weight fill as large as $15.2 \mathrm{~g} / \mathrm{kg} \mathrm{BM}$ has been recorded in winter (Staaland \& Thing 1991).

However, if the omasum functions primarily as an organ of absorption, the key parameter must be its tissue surface area rather than its mass. The mucosa of the omasum has a very large surface area owing to the presence of a large number of leaves attached to the dorsal wall. In late summer and early winter the total absorptive surface area of the omasum of reindeer ranged from 1867 to $2514 \mathrm{~cm}^{2}$ (Table 5) which is larger than that found in moose, a large CS, in which the total absorptive surface area of the omasum was approximately $1820 \mathrm{~cm}^{2}$ (Hofmann \& Nygren 1992, Werner 1990). These values are small compared to cattle, a typical GR (absorptive area $42010 \mathrm{~cm}^{2}$ ) but when converted into the surface area index (SAI), the values for both sub-species of reindeer (range $55-113 \mathrm{~cm}^{2} / \mathrm{BM}^{0.75}$, Table 5) are intermediate between the value for CS like the moose (SAI $26.6 \mathrm{~cm}^{2} / \mathrm{BM}^{0.75}$, Werner 1990) and the roe 
deer (SAI $25.4 \mathrm{~cm}^{2} / \mathrm{BM}^{0.75}$, Table 5) and GR like cattle and bison (SAI 549 and 212 $\mathrm{cm}^{2} / \mathrm{BM}^{0.75}$, respectively; Table 5). The absorptive surface of the omasum is, therefore, relatively small in reindeer which is consistent with their classification as IM ruminants (Hofmann 1985).

Another possible function of the omasum is the enhancement of the transport of ingesta from the reticulum to the abomasum by aspiration or muscular pumping (Sellers \& Stevens 1966). The larger size of the omasum and the larger diameter of the reticulo-omasal orifice of Svalbard reindeer compared to Norwegian reindeer in winter might, therefore, promote more rapid passage of digesta out of the RR. Small particles do seem to be more efficiently released from the rumen in Svalbard reindeer both in summer and in winter. The RR of Norwegian reindeer contained a very high $(>90 \%)$ proportion of plant particles $<1 \mathrm{~mm}$ in greatest length while in Svalbard reindeer the value was approximately only 70\% (Mathiesen et al. 1999b, Sørmo et al. 1999). The flow of digesta from the rumen into the omasum, however, is mainly regulated by the relative density of the plant particles (Lechner-Doll et al. 1995) and we do not yet know the relationship between the size and density of particles from different species of plants in the RR of reindeer. The large DFC (10\%-17\% RR content) in Svalbard reindeer is similar in size to roe deer (Table 3) but larger than in Norwegian reindeer ( $8 \%$ of RR content) perhaps indicating more rapid escape of ingesta from the rumen and omasum to the abomasum in the former (Sørmo et al. 1999, Mathiesen et al. 1999b).

It is also conceivable that the omasum of IM ruminants like reindeer enhances the bypass of nutrients along the canalis omasi to the abomasum. Meyer et al. (1998) and Rowell et al. (1997) have provided strong evidence for the functional significance of the purported bypass of soluble metabolites. Hofmann (1985) suggested that some adult ruminants maintain the sulcus ventriculi, which is well developed for the bypass of nutrients directly into the abomasum throughout life but it remains to be shown whether the reticular groove functions in this manner in adult reindeer. Irrespective of this, our results show that the omasum is not conservative but is a seasonally dynamic and adaptable organ in the gastrointestinal tract of reindeer.

\section{Acknowledgements}

This work was supported by the Reindeer Husbandry Research Fund (Norwegian Ministry of Agriculture) and by the Norwegian Research Council. We thank reindeer herder Mathis A. Sara of Karasjok for allowing us to use his reindeer, the crew of the Norwegian coastguard K/V 'Senja', the Governor of Svalbard and Dr. Rolf Langvatn UNIS, Svalbard, Mr. Justin Irvine, Institute of Zoology, London for support with fieldwork on Svalbard and Kirsti Johnsen and Turid Kaino for skilful technical support.

\section{References}

Aagnes TH, Mathiesen SD: Gross anatomy of the gastrointestinal tract in reindeer, free-living and fed baled timothy silage in summer and winter. Rangifer. 1996, 16, 31-39.

Chan-McLeod ACA, White RG, Holleman D: Effect of protein and energy intake, body condition, and season on nutrient partitioning and milk production in caribou and reindeer. Can. J. Zool, 1994, 72, 938-947.

Glen AR: Under the Pole Star. Methuen, London $1937.365 \mathrm{pp}$.

Hindrum R, Jordhøy P, Strand O, Tyler NJC: Svalbardrein: Et nøysomt liv på tundraen. (Svalbard reindeer: a thrifty life on the tundra). Villreinen 1995, 105-112.

Hofmann RR, Stewart DRM: Grazer or browser: A classification based on stomach structure and feeding habits of East African ruminants. Mammalia, Paris 1972, 36, 226-240.

Hofmann RR: The ruminant stomach: Stomach structure and feeding habits of East African Game Ruminants. East African Monograph in Biology. Vol 2. Nairobi: East African Literature Bureau. 1973. $354 \mathrm{pp}$. 
Hofmann RR: Digestive physiology of deer - Their morphophysiological specialization and adaptation. In: Fennessy, P. Drew, K. (eds): Biology of Deer Production. The Royal Society of New Zealand Bulletin 1985, 22, 393-407.

Hofmann RR: Evolutionary steps of ecophysiological adaptation and diversification of ruminants: a comparative view of their digestive system. Oecologia 1989, 78, 443-457.

Hofmann RR: Functional and comparative digestive system anatomy of Arctic ruminants. 2000. Rangifer. In press.

Hofmann RR, Nygren K: Morphophysiological specialization and adaptation of moose digestive system. Alces. 1992. Suppl. 1 pp 91-100.

Holand Ø: Winter digestive strategy of a concentrate selector in Norway: the European roe deer. Can. J. Zool. 1992, 70, 1331-1335.

Holand Ø, Staaland H: Nutritional Strategies and winter survival of European roe deer in Norway. In: Fennessy, P., Drew, K. (eds.): Biology of Deer Production. The Royal Society of New Zealand Bulletin 1985, 22, 423-428.

Jacobsen E, Skjenneberg, S: Experiments with different diets to reindeer. Feeding value of reindeer feed (RF-71). Scientific report, Agricultural College, Norway, 1975, 58, 1-11.

Larsen TS, Nilsson NØ, Blix AS: Seasonal changes in lipogenesis and lipolysis in isolated adipocytes from Svalbard and Norwegian reindeer. Acta Physiologica Scandinavia 1985, 123, 97-104.

Lechner-Doll M, Hume ID, Hofmann RR: Comparison of herbivory forage selection and digestion. In: M. Journet, Grenet, E., Farce, M-H., Theriez, M., Demarquilly, C. (eds): Recent developments in the Nutrition of herbivores. Proceeding of the 4th Intern. Symp. on the Nutrition of Herbivores, 1995, 231-248, INRA Editions, Paris.

Mathiesen SD, Orpin, CG, Blix AS: Rumen microbial adaptation to fibre digestion in Svalbard reindeer. Can. J. Anim. Sci. 1984, 64, 261-262.

Mathiesen, SD, Raedergård, VB, Vader, MA, Haga, $\emptyset E$, Norberg, HJ, Sørmo, W, \& Tyler, NJC: Salivary glands in Svalbard reindeer (Rangifer tarandus platyrhynchus) and in Norwegian reindeer (Rangifer t. tarandus). Rangifer 1999a, 19, 2532.

Mathiesen SD, Sørmo W, Aagnes TH: Forage chemistry and the digestive system in reindeer (Rangifer tarandus tarandus) in northern Norway and on South Georgia. Rangifer.1999b, 19, 91-101.

Mathiesen, SD, Sørmo, W, \& Aagnes Utsi TH: Com- parative aspects of volatile fatty acid production in reindeer (Rangifer tarandus tarandus) in northern Norway and on South Georgia. 2000a. Rangifer. In press.

Mathiesen SD, Haga, Ø.E., Kaino, T, \& Tyler, NJC: Diet composition, rumen papillation and maintenance of carcass mass in Norwegian reindeer in winter. J. Zool. London 2000b, 250. In press.

Meyer HHD, Rowell A, Streich WJ, Stoffel B, Hofmann, RR: Accumulation of polyunsaturated fatty acids by concentrate selecting ruminants. Comp. Biochem. Physiol. A 1998, 120, 263-268.

Person SJ, White RG, Luick JR: Determination of nutritive value of reindeer caribou range. In: Reimers E, Gaare E, Skjenneberg S (eds.): Proc. of the $2^{\text {nd }}$ Inter. Reinder and Caribou Symposium. Direktoratet for vilt og ferskvannsfisk. Trondheim 1980, 224-239.

Reed JD: The nutritional ecology of game and cattle on a Kenyan ranch 1983. PhD thesis Cornell Univ. Ithaca, N.Y.

Reimers E, Ringberg T, Sørumgaard R: Body composition of Svalbard reindeer. Can. J. Zool. 1982, 60, 1812-1821.

Rowell A, Dye J, Hofmann RR, Lechner-Doll M, Meyer HHD, Shirazi-Beechey SP, Wood IS: The expression of intestinal sodium-glucose cotransporter in cervids. Zschr. Saeugetierkunde 1997. Suppl. 2, 62, 204-208.

Sellers $A F$, Stevens $C E$ : Motor functions of the ruminant forestomach. Physiol. Rev. 1966, 46, 634661.

Staaland H, Jacobsen E, White RG: Comparison of the digestive tract in Svalbard and Norwegian reindeer. Arctic and Alpine Research 1979, 11, 457-466.

Staaland H, Punsvik, T: Reindeer grazing on Nord Austlandet, Svalbard.- In: E. Reimers, E. Gaare and S. Skjenneberg (eds.): Proc. 2nd. Int. Reindeer and Caribou Symposium. Direktoratet for vilt $\mathrm{og}$ ferskvansfiske, Trondheim 1980, 142-150.

Staaland H, Brattbakk I, Ekern H, Kildemo K: Chemical composition of forage plants in Svalbard and Norway. Holarctic Ecology. 1983, 6, 109-122.

Staaland H: On the quality of Svalbard reindeer pasture in the summer and autumn. 1984. Rangifer. 4 (1) $16-23$.

Staaland $H$, Thing $H$ : Distribution of nutrients and minerals in the alimentary tract of muskoxen, Ovibos moschatus. Comp. Biochem. Physiol. 1991, 98A, 543-549.

Staaland $H$, White $R G$ : Influence of foraging ecology 
on alimentary tract size and function of the Svalbard reindeer. Can.J. Zool. 1991, 69, 1326-1334.

Sørmo W, Haga ØE, White RG, Mathiesen SD: Comparative aspects of volatile fatty acids in the fermention chambers in Svalbard reindeer. Rangifer. 1997, 17, 81-95.

Sørmo $W$, Haga ØE, Gaare. E, Langvatn $R$, Mathiesen $S D: 1999$. Plant dietary effect on the fermentation chambers in Svalbard reindeer. J. Zool., London. 1999, 247, 247-256.

Tulloh NM: Physical studies on the alimentary tract of grazing cattle. New Zeal. J. Agric. Res. 1996, 9, 999-1008.

Tyler NJC: Body composition and energy balance of pregnant and non-pregnant Svalbard reindeer during winter. Zool. Soc. London Symp. 1987, 57, 203-229.

Tyler NJC, Fauchald P, Johansen $O$, Christiansen $H R$ : Seasonal inappetence and weight loss in female reindeer in winter. Ecological Bull 1999, 14, 105-116.

Tyler NJC, Øritsland NA: Why don't Svalbard reindeer migrate? Holarctic Ecology 1989, 12, 369376.

Werner A: Vergleichende morphometrische Untersuchungen am Blattermagen von Wiederkauern (RUMINANTIA) unterschiedlicher Ernahrungstypen. (Investigation of omasum from different ruminant feeding types). Vet Doctorate thesis, Justus-Liebig Universitat, Giessen, Germany, 1990.

White $R G$, Staaland $H$ : Ruminal volatile fatty acid production as an indicator of forage quality in Svalbard reindeer.- Acta Zool. Fennic. 1983, 175, 61-63.

\begin{abstract}
Sammendrag
Bladmagens funksjonelle anatomi i Svalbardrein (Rangifer tarandus platyrhynchus) og fastlandsrein $i$ Nord-Norge (Rangifer tarandus tarandus).
\end{abstract}

Bladmagens struktur og fyllingsgrad ble undersøkt i Svalbardrein som lever på den høy arktiske øygruppen Svalbard og i fastlandsrein fra Nord-Norge fra både sommer- og vinterbeite. Bladmagens gjennomsnittlig størrelse (mean) i ikke lakterende simler var $467 \mathrm{~g}(0.65 \mathrm{~g}$ pr $100 \mathrm{~g}$ levende vekt) i september og $477 \mathrm{~g}$ (1.03 g pr $100 \mathrm{~g}$ levende vekt) i april på Svalbard. I ikke lakterende simler på fastlandet veide bladmagen $534 \mathrm{~g}$ (0.83 g pr $100 \mathrm{~g}$ levende vekt) $\mathrm{i}$ september, men bare $205 \mathrm{~g}(0.35 \mathrm{~g}$ pr $100 \mathrm{~g}$ levende vekt, $\mathrm{p}<0.05)$ i mars. Både vevsmasse og innholdet i bladmagen var redusert i fastlandsreinen om vinteren. Gjennomsnittlig (mean) overflateareal av Svalbardreinens bladmager var $2300 \mathrm{~cm}^{2}$ i september og $2023 \mathrm{~cm}^{2}$ i april. I fastlandsreinen var overflatearealet av bladmagene $2201 \mathrm{~cm}^{2}$ i september, men redusert til bare $1181 \mathrm{~cm}^{2}$ i mars $(\mathrm{p}<0.05)$. Den reduserte bladmagen $\mathrm{i}$ fastlandsreinen skyldes antagelig inntak av høyt fordøyelige beiteplanter som reinlav på vinteren. Svalbardreinen trekker ikke mellom sesongbeiter, men overlever ved å spise fiberrike beiteplanter om vinteren. At Svalbardreinen opprettholder sine store bladmager om vinteren, kan reflektere disse dyrenes behov for å opprettholde en effektiv absorpsjon av næringsstoffer, som flyktige fettsyrer, når beiteplantene er av dårlig kvalitet.

(Received August 1, 1998, accepted September 30, 1999).

Reprints may be obtained from: S. D. Mathiesen, Department of Arctic Veterinary Medicine, The Norwegian School of Veterinary Science, N-92 92 Tromsø, Norway. E-mail: Svein.D.Mathiesen@veths.no, tel: +47 $77665411,+4790524116$, fax: +4777694911 . 